\title{
АВТОР У КООРДИНАТАХ ПАРАДИГМАЛЬНИХ КАТЕГОРІЙ ПОСТМОДЕРНІЗМУ
}

Авторка подає локальний виклад стратегії теоретичної анігілячії суб 'єкта творчості, що, як відомо, інспірувала переосмислення категорії автора в теоретико-методологічних та історико-літературних дослідженнях сучасних украӥнських науковчів.

Ключові слова: автор, суб'єкт творчої діяльності, скриптор, «авторфункиія», «смерть автора».

Автор представляет локальное изложение стратегии теоретической аннигилячии субъекта творчества, которая, как известно, инспирировала переосмысление категории автора в теоретико-методологических и историколитературных исследованиях современных украинских ученых.

Ключевые слова: автор, субъект творческой деятельности, скриптор, «автор-функция», «смерть автора».

It is given a local presentation of strategies of theoretical annihilation of subject of creativity, which, as we know, inspired the redefining of author's category in the theoretical and methodological, historical and literary studies of modern Ukrainian scientists.

Key words: author, subject of creativity, scripter, «author-function», «death of the author».

Досліджуючи проблеми «громадянства і національної ідентичності» щодо специфіки європейського суспільно-історичного процесу, Ю. Габермас зауважував: «До середини 1980-х років історія начебто поступово увійшла в той кристалічний стан, котрий відомий як постісторія, якщо використовувати визначення, дане Арнольдом Геленом для того дивного відчуття, коли "все змінюється, але нічого не рухається далі" <..> Тим часом ией настрій змінився. Історія мобілізувалася, набула пришвидшення $i$ навіть завирувала. Нові проблеми зсувають старі перспективи, 
<...> нові перспективи майбутнього, з 'являються нові точки зору, що відновлюють нашу здатність до розуміння альтернативних напрямів дїі» [Хабермас 2005: 49].

Чи не $з$ більшою вірогідністю можемо адресувати думку відомого політичного філософа й соціолога українським реаліям останнього десятиліття XX століття, позначеним політичною активністю і соціальною креативністю, інституціальними змінами, інтенсивною інтелектуальною роботою. Кардинальні перетворення ініціювали перегляд попередніх наукових досягнень і пошук нових парадигм естетичного досвіду. Зокрема в умовах активного формування посттоталітарного літературознавчого дискурсу окреслилися проблеми не лише «переборення старих уявлень та підходів», але й творення власних, акцентовано орієнтованих на національний досвід теоретико-методологічних концепцій [Дончик 2003: $516,421]$. У сучасних координатах 3-посеред актуальних і «найбільш перспективних» методологічних проблем літератури як науки, за визначенням Г. Сивоконя, постало завдання «осягнення $\mathrm{CAMO}$ ТОТОЖНОСТІ ПИСБМЕННИКА як неповторно-індивідуального ЗАКОНУ творчості, де принципи, вироблені <...> протягом літературного шляху, реалізуються з більшою чи меншою повнотою у цілому творчому спадкові...» [Сивокінь 1999: 7].

Отже, здавалося б, на перший погляд, грунтовно й різноаспектно досліджена попередниками проблема автора-творця в умовах нової літературознавчої парадигми виявилася актуалізованою нагальною потребою «модернізації» теоретико-літературного матеріалу з опорою на власну традицію та критично осмислений зарубіжний досвід. 3 іншого боку, у вітчизняному літературознавстві помежів'я XX-XXI ст. щодо автора й авторства в цілому досить помітно виявилася полярна до традиційної класичної парадигми позиція, теоретичні горизонти якої окреслюються категоріями ігнорування / заперечення статусу автора як повноправного суб'єкта творчої діяльності. Маємо на увазі явище (уперше ініційоване західноєвропейською й американською критикою), означене нау- 
ковцями «кризою авторства» 3 чітко оприявненою тенденцією до деперсоналізації творчого начала та десакралізації авторської позиції. Не вдаючись до коментування чи проекції методології «поструктуралістсько-деконструктивістсько-постмодерністського комплексу» (І. Ільїн) у вітчизняному літературознавчому контексті, дозволимо собі лише локальний виклад стратегії конструювання основного постулату радикальної доктрини - теоретичної анігіляції суб'єкта творчості, що, як відомо, певною мірою інспірувала переосмислення категорії автора в теоретико-методологічних та істориколітературних дослідженнях сучасних українських науковців.

Євро-американський літературно-теоретичний мейнстрим «недовіри» до автора сформувався приблизно в кінці 40-х років XX ст. в контексті відмежування від традиційної метафізики з ії субстанціалізмом, критики філософії ірраціоналізму, інтуїтивізму та «синтетичного гуманізму» (вислів Г. Косікова) й ознаменував собою загальну тенденцію дискредитації особистісного начала. Чимало дослідників сходяться на думці, що імпульсом до критики теорії автора, а згодом - теоретичної ревізії концепції автора в кінці 60-х середині 80-х років стало перенесення дослідницької проблематики зі сфери суб'єктності на лінгвістичний рівень «граматологічного аналізу» (термін Ю. Крістевої) естетичних відношень.

Стаття Р. Барта «Смерть автора», означена «кульмінацією критики ідеології інституту літератури 3 його двома основними опорами: мімесисом і автором» [Ильин 1996: 161], як і проголошена роком пізніше полемічна доповідь М. Фуко «Що таке автор?», задекларувала постструктуралістський варіант «смерті суб'єкта» творчої діяльності - «батька і господаря свого твору». Звернімо увагу, якщо Р. Барт, звертаючись до «постаті Автора», обумовлює його вилучення й заміну сучасним скриптором («суб'єктом писання»), що «несе в собі не пристрасті, настрої, відчуття або враження, а тільки неосяжний словник» [Барт 1989 (2): 389], суто лінгвістичними позиціями, то в інтерпретаційній парадигмі М. Фуко автор розглядається в значно ширшому (філософсько-культурологічному) 
контексті - як «автор-функція», «елемент дискурсу» 3 «вільною циркуляцією» значень [Фуко 1996 (2): 447]. Усвідомлюючи, що «той, хто говорить (у самому творі), - че не той, хто пише (в реальному житті), а той, хто пише, - $\epsilon$ не той, хто існує» [Барт 1987 (2): 412], і Р. Барт, і М. Фуко принципово заперечують ототожнення автора з реальною постаттю митця, «вигаданим оповідачем» чи героєм твору (у цій позиції вони близькі до класичного розуміння суб'єкта в концепціях М. Бахтіна й В. Виноградова. - О. Ф.) і акцентують на нівеляції авторської індивідуальності власне самим процесом «письма».

Між тим М. Фуко, з одного боку, подібно до Р. Барта, проблематизує суб'єктивність автора в умовах нової соціокультурної ситуації, переконуючи в девальвації означеної категорії, з іншого, визнає абсурдність «заперечувати існування суб'єкта, який пише та вигадує». Зрозуміло, осмислюючи в цьому контексті автора не «індивідом, який промовив або написав текст, а принципом групування дискурсів, єдністю і джерелом їхніх значень та чентром їхньої зв 'язності» [Фуко 1996: 64, 62]. Цікаво, що французький культуролог, фокусуючи увагу на «функиіі автора <..> породжувати кілька "я", кількох суб 'єктів» [Фуко 1996 (2): 451], переконливо окреслює роль власного імені автора, тим самим не підтримуючи проголошеної Р. Бартом та іншими постструктуралістами позиції анонімного простору тексту. Як доводить дослідник еволюції постмодернізму І. Ільїн, у роботах пізнішого періоду М. Фуко кардинально переглянув проблематику суб'єкта: «якщо раніше <..> суб 'єкт "умирав" у тексті як його автор, то тепер як "носій волі і влади" суб 'єкт і в ролі автора тексту знаходить деяку, хоч і обмежену, легітимність (а заразом і відносну свободу як активний "відтворювач дискурсивних і сочіальних практик")» [Ильин 1996: 86].

Показово, що подібні суперечності інтерпретаційних підходів не були прерогативою літературно-теоретичних рефлексій одного М. Фуко. Цілком очевидно, вони характерні й для концепції Р. Барта, який із часом відійшов від категорично однозначної по- 
зиції лінгвістичної детермінованості творчого суб'єкта. На думку I. Ільїна, чергова зміна критичної парадигми Р. Барта пов'язана 3 «невдоволенням від практики "текстового аналізу" та долученням аналітика літератури до конщепчії "еротичного тексту"» [Ильин 1996: 155]. Беззаперечними аргументами еволюції поглядів Р. Барта щодо спільної для структуралізму й постструктуралізму ідеї «смерті автора» можуть бути висновки, артикульовані в теоретичних працях початку 70-х років («Від твору до тексту», «Задоволення від тексту»). Маніфестований de jure в «Смерті автора» скриптор, як виявилося, de facto «з'являється» в тексті в образі «привида Автора», «гостя», «Автора на папері», відображається «як один $з$ персонажів, фігура, що виткана на килимі» [Барт 1989 (1): 419].

Подібна дихотомія в процесі теоретичної елімінації категорії автора об'єднує М. Фуко і Р. Барта з Ж. Дерріда, який доводить, що відсутність центру, а відтак, і відсутність автора («трансиендентального означуваного»), є запорукою «можливості гри значень до нескінченності» [Деррида 2000 (1): 354]. Разом із тим припускає, що здатність письма до одночасного руйнування / творення суб'єкта $\epsilon$ «не що інше, як саме конституювання суб'єктивності», яка «здатна з'явитися лише в момент власного зникнення» [Деррида 2000 (2): 196-197]. Посутньо зауважимо: Ж. Дерріда постулює ще й третій варіант обгрунтування власної теоретичної позиції, що наочно підтверджує вразливість концепції «смерті автора»: «я не говорив, що не існує чентру $і$ що ми можемо обходитися без центру. Я вважаю, що чентр є функцісю. ...І ия функція є абсолютно необхідною, як $і$ абсолютно необхідним є суб'єкт. Я не руйную суб 'єкта, я його розташовую. ...Питання полягає тільки в тому, звідки він береться і як функиіонує» [Дискусія 1996: 476].

Власне, амбівалентний характер аргументації усвідомлювався й самими теоретиками постструктуралізму, але інтерпретувався ними «як необхідна діалектика» [Фрайзе 1996: 30]. Як нам видається, сутність означеної «діалектики» в західному літературнокритичному дискурсі авторства прочитується за доволі чіткими 
координатами «ствердження-через-заперечення» або, перефразовуючи сучасного американського аналітика постструктуралістської естетики А. Ліндсея, відтворення категорії автора в самому процесі проголошення його смерті [Lindsay 1995: 20-21].

Активні спроби вилучення автора призвели до зміни акцентів. Зокрема рецептивна естетика й критика визнали найважливішою категорією, «законним» творцем літературного тексту читача «особу без історії, без біографії, без психології» [Барт 1989 (2): 390], що зводить в єдине ціле всі смислові лінії «письма». Феноменологія, фокусуючи увагу на свідомості як властивості суб'єкта творчо «вписувати» окремі події, явища, враження, відчуття в тотальне поле інтелектуального предметного конструювання, констатувала функціонування в тексті «плинного» «я» автора, яке оприявнює не «буття-свідомість», а «становлення-свідомість» [Рикер 1995: 269] (хоча про абсолютне заперечення автора як текстуальної категорії ні в рецептивній - В. Ізер, Г. Р. Яусс, ні у феноменологічній теорії не йшлося. $-O$. Ф.).

Цілком очевидно також, що радикальна переакцентація позиції автора за формулами «смерті автора», «авторської функції», «децентрації» суб'єкта актуалізувала «народження» нових категорій, точніше, «нове обтрунтування й новий праксис старих категорійімен» [Созина 2006: 91]. Означене явище має, скажімо, безпосереднє відношення до концепції інтертекстуальності Ю. Крістевої. Творчо переосмисливши теорію діалогізму М. Бахтіна, акумулювавши ідеї Р. Барта, Ж. Дерріда, М. Фуко, дослідниця атрибутувала власний літературно-теоретичний проект, що визначав позицію «суб 'єктав-прочесі» (термін Т. Мой) пізнання мистецтва й історії, а відтак і позицію автора як «перетворену в пустий простір проекиію інтертекстуальної гри» [Intertextualitat 1985]. Стверджуючи, що діалог виводить особистість із гри, одна з найпослідовніших теоретиків літературознавчого постструктуралізму постулює думку щодо імперсонального характеру «гри», у якій авторові (оскільки «він ніхто і ніщо» в тексті) визначається лише «роль провідника» 3 іс- 
торії в дискурс, і навпаки. Автор «стає втіленням анонімності, зяяння, пропуску для того, щоб набула існування структура як така» [Кристева 2000: 439], - вважає Ю. Крістева. Перебування творця в «лоні цієї анонімності, нуля», за логікою дослідниці, проектує Іншого, категорію читача-інтерпретатора, який і репрезентує функцію автора як смислового центру літературного тексту.

Вилучення зі сфери художньої комунікації «герой - автор читач» найважливішого елемента, як засвідчує досвід найновіших наукових студій, спровокувало «вседозволеність читача та його уяви в продукуванні нескінченної, неконтрольованої ланџюгової реакції рецепцій художнього тексту» [Зубрицька 1996: 13]. У свою чергу презумпція множинності інваріантних прочитань, уседозволеність герменевтичного тлумачення, відсутність аргументованих критеріїв для визначення смислу художнього твору, мовний релятивізм тощо стали вагомими аргументами у зворотній реакції«реанімації» автора-творця. Антиавторським тенденціям як спробам звільнитися від більш важливих категорій, зокрема - від відповідальності сучасні дослідники протиставили принцип діяльності, в основі якого естетична формула М. Бахтіна «мистецтво і відповідальність». Як авторитетно заявляє М. Фрайзе, лише за допомогою бахтінського терміна відповідальності можливо відновити автора як центр, навколо якого кристалізується художній смисл [Фрайзе 1996: 32]. Відтак, на зміну дискурсивному аналізу без індивідуального автора приходить реабілітація старих концепцій, пов'язаних з історизмом і психологізмом. Конкретним результатом зрушення в сучасній гуманітаристиці можна визнати формування напряму «нового історизму», який «легалізує прямі зіставлення між ідеями автора та його життям, між теоріями епохи та їі практиками», досліджує в тексті не логічні протиріччя, а втілення ситуативних проблем автора та його часу.

В означеному контексті теоретичної «смерті автора» закономірно виникає питання: якою мірою ця ідея знайшла відгук у вітчизняній науці про літературу? Послуговуючись словами I. Фізера 
можна говорити, що в українському літературознавстві ні «смерть автора», ні «смерть літератури» широкого емпіричного втілення [Фізер 2003: 52] не знайшли. Інакше кажучи, у вітчизняному гуманітарному просторі не відбулося елімінації індивідуального авторства ні як культурного інституту, ні як предмета літературознавчого інтересу (що, власне, засвідчують грунтовні наукові студії 1980-1990 рр. В. Смілянської, О. Астаф'єва, Т. Волкової та ін.). Більшість українських дослідників сходяться на думці, що проблема автора, «найголовнішого рушія літературного процесу», була й залишається центральною в сучасній філологічній парадигмі: «заперечувати існування автора-людини, че заперечувати існування автора-Барта, автора-Фуко. Заперечувати існування структури та ї ядра - це заперечувати існування Сония, Землі, Парижа, людини» [Ткаченко 2000: 11]. Не вдаючись до аналізу природи такого феномену, серед об'єктивних причин, що визначали пріоритет авторства в літературно-критичній парадигмі радянського періоду, виокремимо насамперед суспільно-політичний фактор. У складних умовах ідеологічного диктату діяльність автора-творця інтерпретувалася не лише у творчому, а в значно ширшому - національному, соціальному, історичному контекстах. Окрім того в гуманітарній парадигмі країн соціалістичної орієнтації (зокрема в польських і чеських структуралістів) питання про автора художнього твору ніколи не було цілком проігнорованим, хоча б через тиск марксистської літературної критики.

Зрозуміло, що після тривалого перебування у специфічній зоні регламентації вітчизняне літературознавство інтенсифікувало прагнення до набуття методологічної самостійності (навіть в умовах схильності сьогоденних наукових проектів до «аплікації» сучасних зарубіжних теоретико-методологічних схем на український матеріал. - О. Ф.). І цей процес, без сумніву, став каталізатором наукової обсервації проблеми автора на матеріалі національної як класичної, так і сучасної літератури. Предметом грунтовних студій постали стратегії конструювання (О. Корабльов) та типологія «об- 
разу автора» (С. Руссова), диференціація структури авторської самореалізації (О. Бондарева), форми функціонування «авторського голосу» (О. Лапко), специфіка співвідношення автора й персонажа (Я. Масалха), автора й читача (Т. Черкашина), проблеми авторської свідомості (М. Кодак, М. Гірняк) та форми ії вираження в тексті (В. Галацька, А. Островська, Г. Шередека), статус автора у творах драматичного роду (М. Шаповал) тощо. Комплексною спробою узагальнити теоретико-літературні здобутки, точніше, співвіднести попередні досягнення з досвідом сучасної гуманітарної думки та практики, стало видання колективних наукових збірників «Проблема автора: онтологія, типологія, діалог», «Автор і авторство у словесній творчості». По суті, вперше за останні два десятиліття українські та зарубіжні вчені на аналітичному полі спільного видання, засвідчивши подібність ключових установок, не лише чітко специфікували проблематику суб'єкта творчої діяльності в сучасному критичному дискурсі, але й запропонували чимало конструктивних положень стосовно нової стратегії осмислення категорії автора.

Разом із тим, незважаючи на позитивну динаміку останніх років щодо літературно-теоретичної реактуалізації категорії автоpa, 3 точки зору теоретика літератури В. Федорова, важлива проблема «опинилась практично на периферії уваги вчених» [Федоров 2003: 55]. На думку метра донецької філологічної школи, автор і авторство повинні стати предметом особливої сфери знань («нової філології», «постфілології» чи «метафілології»), яка б дозволила знайти «адекватний підхід до такої величини». Виходячи з того, що ні фундаментальне дослідження «автора... в естетичній діяльності» М. Бахтіна, ні суб’єктно-об'єктна системологія Б. Кормана «у чистому» вигляді (тобто тільки у філософсько-методологічній системі координат або лише в межах поетики) не можуть бути релевантними для «вирішення» проблеми автора, В. Федоров репрезентує методику вивчення автора як «онтологічної проблеми» [Федоров 2006; Федоров 2003; Федоров 1998; Федоров 2002]. 
Зрештою, підсумовуючи власні спостереження, виокремлюємо загальний вектор осмислення гуманітарною думкою XX ст. проблеми автора, який умовно можна окреслити теоретичними парадигмами, класифікованими за рівнем визнання / заперечення автора як самостійної літературної категорії. Оскільки жоден «семіотичний механізм не може функиіонувати як ізольована, занурена у вакуум система» [Лотман 2000: 642], можемо стверджувати, що обидві парадигми в дискурсі авторства вступали в конвергентні відносини між собою, утворюючи на більш високому рівні «біполярну єдність». Зв'язок виявлених у динаміці культурного процесу минулого та початку нового століття одночасно протилежних і взаємодоповнюваних тенденцій - теорій визнання / заперечення автора - дозволяє кожній із них, перебуваючи в стані «структурної антонімії, культивувати власну специфіку й взаємну контрастність» [Лотман 2000: 643].

\section{БІБЛІОГРАФІЯ}

Барт 1987 - Барт Р. Введение в структурный анализ повествовательных текстов /

Р. Барт // Зарубежная эстетика и теория литературы XIX-XX вв. : трактаты, статьи, эссе / сост., общ. ред. Г. К. Косикова. - М. : Изд-во Московского университета, 1987. - С. 387-422.

Барт 1989 (1) - Барт Р. От произведения к тексту / Р. Барт // Избранные работы : Семиотика : Поэтика / пер. с фр. ; сост., общ. ред и вступ. ст. Г. К. Косикова. М. : Прогресс, 1989. - С. 413-423.

Барт 1989 (2) - Барт Р. Смерть автора / Р. Барт // Избранные работы : Семиотика : Поэтика / пер. с фр. ; сост., общ. ред. и вступ. ст. Г. К. Косикова. - М. : Прогресс, 1989. - С. 384-391.

Деррида 2000 (1) - Деррида Ж. Лингвистика и грамматология / Ж. Деррида // О грамматологии / пер. с фр., вступ. ст. Н. Автономовой. - М. : Ad Marginem, 2000. - C. 192-203.

Деррида 2000 (2) - Деррида Ж. Структура, знак и игра в дискурсе гуманитарных наук / Ж. Деррида // Письмо и различие / пер. с фр. А. Гараджи, В. Лапицкого и С. Фокина ; сост. и общ. ред. В. Лапицкого. - СПб. : Гуманитарное агентство «Академический проект», 2000. - С. 352-368.

Дискусія 1996 - Дискусія (Ж. Іпполіт, Ж. Дерріда, Р. Максі, Л. Гольдман, С. Дубровські) // Антологія світової літературно-критичної думки ХХ ст. / за ред. М. Зубрицької. - Львів : Літопис, 1996. - С. 473-477.

Дончик 2003 - Дончик В. Г. 3 потоку літ і літпотоку / Віталій Дончик. - К. : ВД «Стилос», 2003. $-556 \mathrm{c}$.

Зубрицька 1996 - Зубрицька М. Передмова до другого видання / Марія Зубрицька // Антологія до світової літературно-критичної думки ХХ ст. / за ред.

М. Зубрицької. - Львів : Літопис, 2002. - С. 9-14. 
Ильин 1996 - Ильин И. Постструктурализм. Деконструктивизм. Постмодернизм / Илья Ильин. - М. : Интрада, 1996. - 255 с.

Кристева 2000 - Кристева Ю. Бахтин, слово, диалог и роман / Ю. Кристева // Французская семиотика : От структурализма к постструктурализму / пер. с фр., сост., вступ. ст. Г. К. Косикова. - М. : ИГ «Прогресс», 2000. - С. 427-457.

Лотман 2000 - Лотман Ю. М. Семиосфера. Культура и взрыв. Внутри мыслящих миров. Статьи. Исследования. Заметки / Ю. М. Лотман. - СПб. : ИскусствоСПб, 2000. - $704 \mathrm{c.}$

Рикер 1995 - Рикер П. Конфликт интерпретаций: Очерки о герменевтике / Поль Рикер. - М. : Academia-Центр, «Медиум», 1995. - 411 с.

Сивокінь 1999 - Сивокінь Г. «Самототожність письменника» як методологічна пропозиція / Г. Сивокінь // Самототожність письменника. До методології сучасного літературознавства : колективна монографія / відп. ред.

Г. М. Сивокінь. - К. : Українська книга, 1999. - С. 6-21.

Созина 2006 - Созина Е. К. Категория автора в постфиналистскую эпоху / Е. К. Созина // Проблема автора: онтологія, типологія, діалог : літературознавчий збірник. - Донецьк : ДонНУ, 2006. - Вип. 25. - С. 90-107.

Ткаченко 2000 - Ткаченко А. Між Хаосом і Космосом, або У передчутті неоструктуралізму / Анатолій Ткаченко // Слово і час. - 2000. - № 2. - С. 1115.

Федоров 2006 - Федоров В. Автор как субъект творческого бытия / В. В. Федоров // Проблема автора: онтология, типология, диалог : литературоведческий сборник. - Донецк : ДонНУ, 2006. - Вып. 25. - С. 6-11.

Федоров 2003 - Федоров В. Автор як онтологічна проблема / Володимир Федоров // Слово і час. - 2003. - № 10. - С. 55-58.

Федоров 1998 - Федоров В. Поэтический мир и творческое бытие / Владимир Федоров. - Донецк : Кассиопея, 1998. - 80 с.

Федоров 2002 - Федоров В. В. Три лекции об авторе : монография / Владимир Федоров. - Донецк : ООО «Юго-Восток, ЛТД», 2002. - 86 с.

Фізер 2003 - Фізер І. Чи таки смерть автора? (Ретроспективний погляд на тему, що не хоче зникнути) / Іван Фізер // Слово і час. - 2003. - № 10. - С. 50 -55.

Фрайзе 1996 - Фрайзе М. После изгнания автора. Литературоведение в тупике? / Маттиас Фрайзе // Автор и текст : сб. статей / под ред. В. Марковича и В. Шмида]. - СПб. : Изд-во СПб. ун-та, 1996. - Вып. 2. - С. 25-32.

Фуко 1996 (1) - Фуко М. Воля к истине: по ту сторону знания, власти и сексуальности. Работы разных лет / Мишель Фуко. - М. : Магистериум, 1996. - 447 с.

Фуко 1996 (2) - Фуко М. Що таке автор? / Мішель Фуко // Слово. Знак. Дискурс : антологія світової літературно-критичної думки ХХ ст. / за ред. М. Зубрицької. - Львів : Літопис, 1996. - С. 444-455.

Хабермас 2005 - Хабермас Ю. Громадянство і національна ідентичність / Ю. Хабермас // Умови громадянства : зб. статей / за ред. Барта ван Стінбергена ; пер. з англ., передм., прим. О. О. Іваненко. - К. : Український Центр духовної культури, 2005. - С. 49-70.

Intertextualitat 1985 - Intertextualitat: Formen, Funktionen, anglist. Fallstudien / Hrsg. von Broich U., Pfister M. - TObingen, 1985. - XII. - 373 S.

Lindsay 1995 - Lindsay A. Death in the FUNhouse. John Barth and Poststructuralist Aesthetics / A. Lindsay. - N.Y. : Peter Lang, 1995. - 176 p. 